Gut, 1988, 29, 1093-1097

\title{
Cytosolic retinoic acid binding protein in the human pancreas
}

\author{
J K JUTLEy, J KELlEHER, T G BRENNAN, M E DENYER, \\ AND C J MITCHELL \\ From the Departments of Medicine and Surgery, St James's University Hospital, Leeds
}

\begin{abstract}
SUMMARY Cytosolic retinoic acid receptor in carcinoma, chronic pancreatitis, and normal pancreatic tissue were examined using sucrose density gradient centrifugation, isoelectric focussing on agarose gel and saturation analysis. Thirteen patients were studied. Cytosolic retinoic acid binding protein (CRABP) was detected in all the samples with chronic pancreatitis and pancreatic carcinoma, but not in the normal tissue. Using sucrose gradient centrifugation, the highest concentrations of CRABP were found in pancreatic carcinoma tissues, ranging from 5.5-23.9 $\mathrm{pmol} / \mathrm{mg}$ protein. These concentrations were markedly different than in chronic pancreatitis tissue (0.7-2.7 $\mathrm{pmol} / \mathrm{mg}$ protein). Saturation analysis of cRABP showed a mean dissociation constant of $21.5 \mathrm{nM}$ and maximum binding sites of $5 \cdot 2 \mathrm{pmol} / \mathrm{mg}$ protein. Cytosolic retinoic acid binding protein was separated at an isoelectric point of 4.5 on agarose gel. The presence of CRABP suggest that retinoic acid may have a role to play in the function of the pancreas.
\end{abstract}

Retinoic acid is essential for normal growth and differentiation of epithelial cells. There is a large body of evidence to suggest that retinoic acid and its synthetic analogues may prevent preneoplastic changes caused by carcinogens in epithelial cells. ${ }^{1-3}$ Chemically induced benign and malignant states in in vitro systems were prevented by vitamin $\mathrm{A}$ and its analogues. ${ }^{46}$ Thaller and Eichele ${ }^{7}$ have recently reported that chick limb buds contain endogenous retinoic acid which acts as a chemical mediator with morphogenic properties.

The mechanism by which retinoic acid mediates its effects is poorly understood. Murtaugh et $a^{8}$ reported that retinoic acid induces alteration in gene expression, as seen on normal and leukaemic myeloid cells, whereby retinoic acid enhances tissue transglutaminase mRNA concentrations. It is thought to act through specific binding proteins, in a manner analogous to steroid hormones, which control differentiation of target organs. ${ }^{910}$ Cytosolic retinoic acid binding protein have been shown in various human tissues including breast, lung, ovary,

Address for correspondence: Dr J K Jutley. PhD, Dept of Medicine, St James`s Hospital, Leeds LS9 7TF

Received for publication 18 February 1988. bladder, prostate, and epidermoid carcinoma. ${ }^{11-17}$ It has been reported that the presence of $C R A B P$ in various carcinoma tissues may suggest retinoic acid as a clinical marker and may be of future therapeutic relevance..$^{13}$ The presence of specific RABP in the human pancreas would suggest that it is a target organ for retinoic acid and therefore the aim of this study was to examine human pancreatic tissue for the presence of $c R A B P$. The presence of $c R A B P$ in human pancreas has not been reported previously in the literature.

\section{Methods}

PATIENTS

Fresh pancreatic tissue was collected at operation from 13 patients (aged $43-80$ years) undergoing total or subtotal pancreatectomy. The tissue used was taken immediately adjacent to that used for histology. Based on histopathology, seven patients were subsequently shown to have chronic pancreatitis, and three patients had carcinoma of the pancreas. Three normal pancreatic tissue samples were collected from organ donors.

All-trans-11, 12 retinoic acid, sodium molybdate, 
activated charcoal and dextran were purchased from Sigma Chemical Co Ltd, UK. Ultrapure sucrose was purchased from Serva, Feinbiochemica, Heidelberg. All other chemicals were bought from BDH Chemicals, UK. All-trans-11, 12-[ $\left.{ }^{3} \mathrm{H}\right]$ retinoic acid (specific activity $860 \mathrm{GBq} / \mathrm{mmol}$ ) was a generous gift from Hoffmann La Roche, Basel. Retinoic acid was stored at $-70^{\circ} \mathrm{C}$ and the purity checked monthly by thin layer chromatography using cyclohexane:ethyl acetate $(3: 2: \mathrm{v} / \mathrm{v})$ as a solvent system. The purity of the compound never fell below $87 \%$.

\section{TISSUE PREPARATION}

Freshly obtained pancreatic tissue was collected on ice, immediately frozen in liquid nitrogen and stored at $-70^{\circ} \mathrm{C}$ until assayed. All further procedures were carried out at $4^{\circ} \mathrm{C}$. One to two grams of tissue was washed in $0.9 \%$ ice cold saline and blotted dry. The tissue was pulverised using a Braun MikroDismembrator II (FI Scientific Instruments Ltd, Tewkesbury, Glos, UK) and suspended in $2 \times$ the

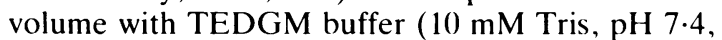
$1.5 \mathrm{mM}$ EDTA, $10 \mathrm{mM}$ dithiotheitol (DTT), $1.4 \mathrm{M}$ glycerol, $5 \mathrm{mM}$ sodium molybdate). The suspension was centrifuged at $100000 \times g$ for one hour at $4^{\circ} \mathrm{C}$, in a swing-out rotor (MSE Superspeed 65) to obtain the cytosolic fraction.

SUCROSE DENSITY GRADIENT CENTRIFUGATION One hundred and eighty microlitres of cytosol was incubated with $\left[{ }^{3} \mathrm{H}\right]$ retinoic acid $(60 \mathrm{nmol})$ in the presence and absence of 100 -fold excess unlabelled ligand at $4^{\circ} \mathrm{C}$ in the dark for 18 hours. Unbound retinoic acid was removed by adding $20 \mu$ l charcoal (2.5\% activated charcoal, $0 \cdot 25 \%$ dextran in TED

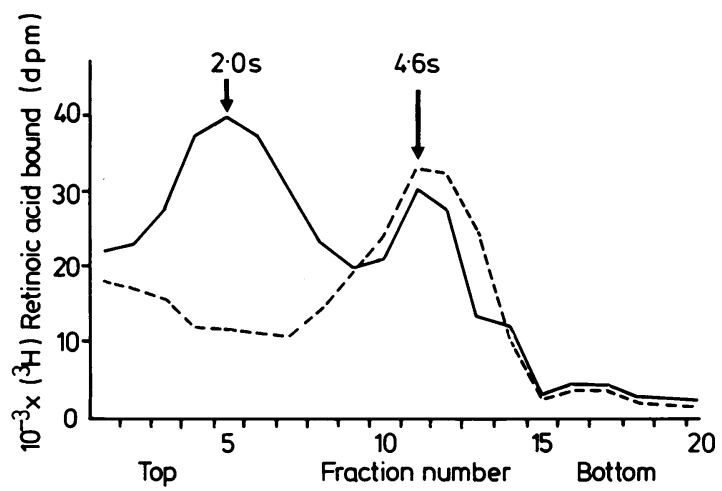

Fig. 1 Demonstration of cytosolic retinoic acid binding protein in human pancreas by sucrose density centrifugation. - cytosol incubated with $[\mathrm{H}] \mathrm{H}$ retinoic acid only. cytosol incubated with [ $\mathrm{H}]$ retinoic acid plus 100 -fold excess of unlabelled retinoic acid. Specific retinoic acid binding in the $2 S$ region is completely inhibited by unlabelled retinoic acid.

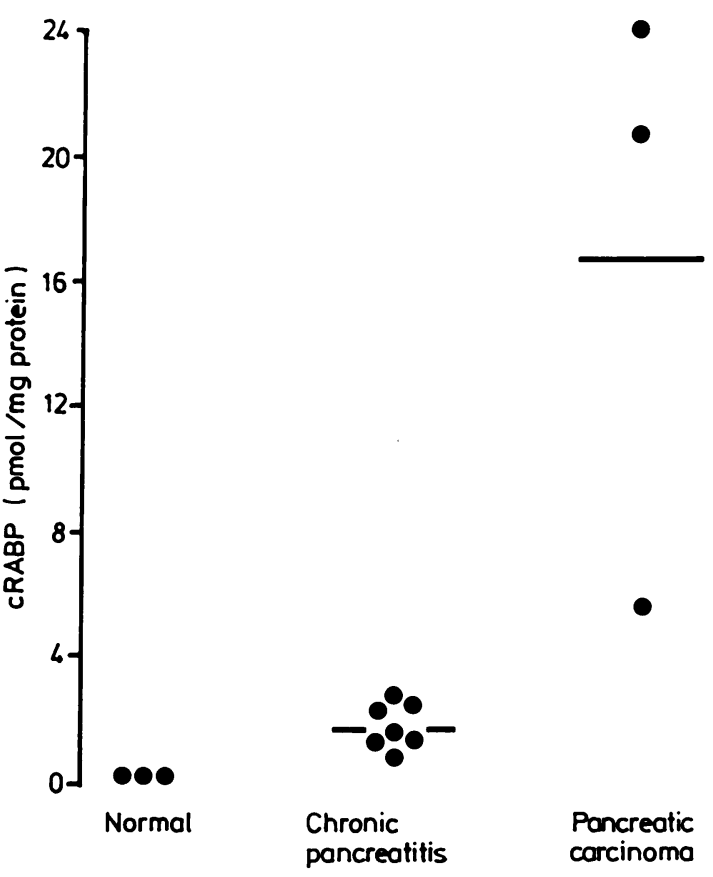

Fig. 2 Distribution of $c R A B P$ in normal and diseased human pancreas using sucrose density gradient analysis.

buffer $-10 \mathrm{mM}$ Tris, pH 7.4, $1.5 \mathrm{mM}$ EDTA, $10 \mathrm{mM}$ DTT) to the incubate. After 10 minutes incubation, charcoal was sedimented by centrifugation at 1500$) \times$ $g$ for 10 minutes at $4^{\circ} \mathrm{C}$.

Two hundred microlitres of the above supernatant was layered onto a 5 to $20 \%(\mathrm{w} / \mathrm{v})$ sucrose gradient and centrifuged at $400000 \times g$ for 22 hours. External standards (myoglobin and bovine serum albumin) were run on separate gradients to locate the $2.0 \mathrm{~S}$ and $4.6 \mathrm{~S}$ fractions respectively. Two hundred microlitre fractions were harvested and the amount of radioactivity counted. Protein content was determined using the Bradford ${ }^{18}$ method.

Twenty microlitres of the above supernatant (after the charcoal step) was also run on a 1\% 'IEF' agarose containing ampholines at $\mathrm{pH} 2.5$ to $\mathrm{pH} 5$ and $\mathrm{pH} 3.5$ to $\mathrm{pH} 10$ at $150 \mathrm{v}$ for two hours $\left(4^{\circ} \mathrm{C}\right)$. Radioactivity from $3 \mathrm{~mm}$ gel fractions was counted in a scintillation counter.

RETINOIC ACID BINDING ASSAY

For the saturation analysis, the cytosol was chromatographed on a $0.9 \times 15 \mathrm{~cm}$ column of sephadex G-75 in TE buffer (10 mM Tris, $1.5 \mathrm{mM}$ EDTA, pH 7.4). Protein concentration in the cytosolic retinoic acid binding protein fraction was adjusted to $2 \cdot 0-3 \cdot 5 \mathrm{mg} / \mathrm{ml}$. Fetal calf serum $(0 \cdot 1 \%$, $\mathrm{v} / \mathrm{v})$ was added and $180 \mu \mathrm{l}$ aliquots were incubated 


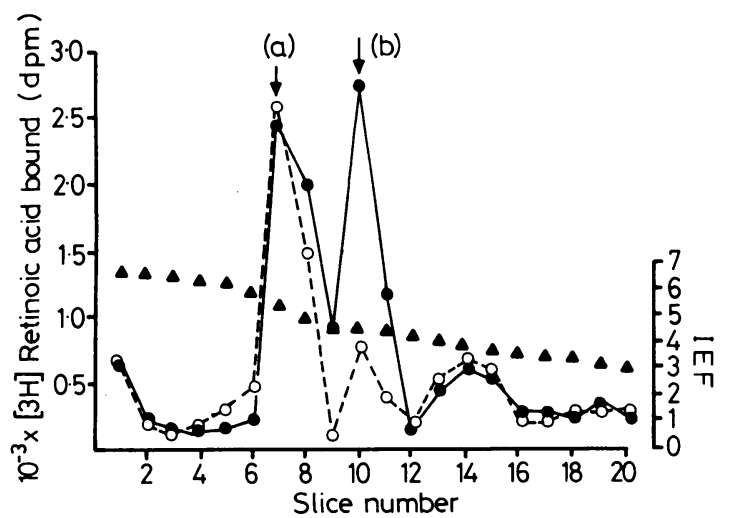

Fig. 3 Isolation of $c R A B P$ in isoelectric focussing on agarose gel. $\mathrm{O}$, cytosol incubated with $/ \mathrm{H} /$ retinoic acid. $0 .[\mathrm{H} /$ retinoic acid plus 100 -fold excess unlabelled retinoic acid. $\boldsymbol{\Delta}, p H$ gradient. Retinoic acid specifically bound to cRABP at an isoelectric point of 4.6 (b) (note the abolition of retinoic acid binding by the excess unlabelled retinoic acid) and non-specific binding is represented by peak $(a)$.

with increasing concentration $(5-60 \mathrm{nmol})$ of $\left[{ }^{3} \mathrm{H}\right]$ retinoic acid for 18 hours at $4^{\circ} \mathrm{C}$ in the presence and absence of 100-fold molar excess of unlabelled ligand. Unbound retinoic acid was removed by the addition of charcoal as described above and the radioactivity determined.

\section{Results}

Sucrose density gradient centrifugation of cytosol incubated with [ $\left.{ }^{3} \mathrm{H}\right]$ retinoic acid revealed a peak at the $2.0 \mathrm{~S}$ region, which coincides with the $2 \mathrm{~S}$ of the external standard. This peak was abolished in the presence of 100 -fold molar excess unlabelled retinoic acid, indicating the specificity of the ligand binding in this region. A profile for $\mathrm{cRABP}$ in the human

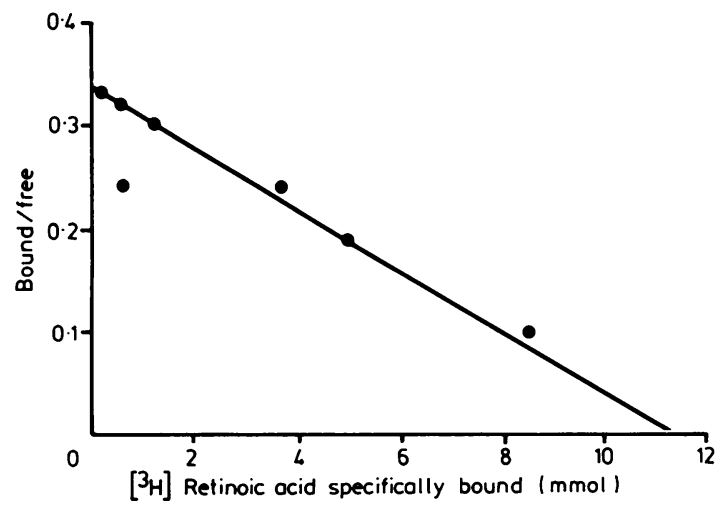

Fig. 4 Scatchard analysis of human pancreatic tissue cytosol. pancreas is shown in Figure 1. The area under the $2 \mathrm{~S}$ peak for each tissue sample was calculated and specific $\mathrm{cRABP}$ was determined as the difference in $\mathrm{dpm}$ between the non-suppressed peak and the suppressed base line. The levels of cRABP varied from $0.7-2.7 \mathrm{pmol} / \mathrm{mg}$ protein in the seven chronic pancreatitis tissue, and from $5.5-23.9 \mathrm{pmol} / \mathrm{mg}$ protein in carcinoma tissue, but was not detected in any of the three normal samples of pancreatic tissue (Fig. 2). There is a clear difference between normal, chronic pancreatitis and carcinoma of the pancreas, and there is no overlap between the three groups. Although the numbers of carcinoma and normal tissues were small, carcinoma of the pancreas clearly had much greater number of $\mathrm{cRABP}$ binding sites compared with normal and chronic pancreatitis tissue.

Figure 3 shows the separation of retinoic acid receptor on IEF agarose. The peak at isoelectric point of 4.5 is abolished when a 100 -fold molar excess cold ligand is added. This peak indicates the specific cRABP site, while the peak at isoelectric point of $5 \cdot 2$ is that of non-specifically bound proteins. The separation of the specific cRABP from nonspecifically bound protein was much clearer on IEF agarose than on sucrose density gradient centrifugation. The results obtained on the IEF agarose gel confirm the data obtained on sucrose density gradient centrifugation.

Scatchard plots, constructed from saturation analysis data from five patients with chronic pancreatitis revealed a single class of high affinity binding sites for retinoic acid in the pancreas (Fig. 4). The dissociation constant was $21.5 \mathrm{nmol}(5 \cdot 7)$ (SE) and the maximum binding capacity was $5.2 \mathrm{pmol} / \mathrm{mg}$ protein $(2 \cdot 6)(\mathrm{SE})$. Saturation analysis with a fixed amount of cytosol incubated with increasing concentration of $\left[{ }^{3} \mathrm{H}\right]$ retinoic acid showed a saturation of binding at $60 \mathrm{nmol}$ retinoic acid.

\section{Discussion}

The saturation analysis of cRABP in the human pancreas is difficult to evaluate because of the different affinity of binding at the $2 \mathrm{~S}$ and the $4.6 \mathrm{~S}$ region. This problem is reduced by subjecting the cytosol to a sephadex G-75 column and obtaining the cRABP fraction for the assay. Protein concentration is adjusted to about $3 \mathrm{mg} / \mathrm{ml}$ before performing the saturation analysis. The mean dissociation constant obtained from a Scatchard plot constructed from the saturation analysis was $21.5 \mathrm{nmol}$ and maximum binding sites of $5.2 \mathrm{pmol} / \mathrm{mg}$ protein. The dissociation constant of $21.5 \mathrm{nmol}$ obtained for the pancreatic tissue was similar to that obtained by $\mathrm{us}^{16}$ for human prostatic tissue $(15.0$ to $31.5 \mathrm{nmol})$ and by 
Siegenthaler and Saurat ${ }^{19}$ for human skin epidermal extract $(13.7 \mathrm{nmol})$.

Cytosolic retinoic acid binding protein has been shown to be distinct from cytosolic retinol binding protein (CRBP) by sucrose density centrifugation ${ }^{15}$ and immunologically. ${ }^{20}$ Using radioimmunoassays, cRBP has been shown to be immunologically distinct from serum RBP.

It is of interest that there was a marked difference between chronic pancreatitis and pancreatic carcinoma tissue. Palan et al $^{12}$ also found significantly raised concentrations of $\mathrm{CRABP}$ in carcinoma tissues from human cervix, endometrium, and ovary compared with normal tissues. Similar trends were reported by Clamon $e t a^{13}$ from lung tissue, Ong $e t$ $a l^{21}$ from lung and breast tissue and Bichler et $a l^{22}$ from squamous cell carcinomas of otorhinolaryngologic region. In clinical assessment of breast and prostatic carcinoma, high concentrations of androgen and oestrogen binding protein are used to predict clinical response to steroid treatment. The observed variation in the specific cRABP concentrations may have a functional significance comparable to steroid receptors. Thus the data on the 10 human pancreatic specimens with chronic pancreatitis and carcinoma of the pancreas, where cRABP was present (albeit at low concentrations in some cases of chronic pancreatitis), suggest that this parameter may be a useful marker for the detection of pancreatic disease. It is possible to assay cRABP on pancreatic biopsy ${ }^{23}$ using the IEF-agarose method. This method has been successfully developed by us for the assay of cRABP in prostatic biopsies. Second, Schwartz et $a^{24}$ reported that retinoic acid has a protective function in Langerhan's cell population in the hamster cheek pouch where it enhances local immune function. In the light of these suggestions, it was postulated that treatment with retinoic acid, in man, may enhance local immune function, and act as prophylactic agent for individuals having a high risk of oral cancer.

If these hypotheses are correct, then the presence of cRABP in chronic pancreatitis and carcinoma tissues may be of significance. It may indicate that treatment with retinoic acid may enhance local immune function and inhibit the risk of pancreatitis and carcinoma in addition to having a functional significance. The numbers of samples presented here is small and further studies are required to support our proposal.

We wish to thank Hoffmann-La Roche, Basle, Switzerland for the generous gift of radio labelled retinoic acid. We also thank the Yorkshire Cancer Research Campaign and the British Digestive Foundation for financial support.

\section{References}

1 Sporn MB, Dunlop NM, Newton DL, Smith JM. Prevention of chemical carcinogenesis by vitamin $A$ and its synthetic analogues (retinoids). Fed Proc 1976; 35: 1332-8.

2 Moon RC, Grubbs CJ, Sporn MB, Goodman DG. Retinyl acetate inhibits mammary carcinogenesis induced by $\mathrm{N}$-methyl-N-nitrosourea. Nature 1977; 267: 620-1.

3 Grubbs CJ, Moon RC, Sporn MB, Newton DL. Inhibition of mammary cancer by retinyl methyl ether. Cancer Res 1977; 37: 599-602.

4 Lasnitzki I. Growth pattern of mouse prostate gland in organ culture and its response to sex hormones, Vitamin A and 3-methylcholanthrene. Natl Cancer Inst Monogr 1963; 12: 381-403.

5 Davis RE. Effect of vitamin A on 7,12-dimethylbenz( $\alpha$ ) anthracene-induced papillomas in rhino mouse skin. Cancer Res 1967; 27: 237-41.

6 Trown PW, Buck MJ, Hansen R. Inhibition of growth and regression of a transplantable rat chondrosarcoma by three retinoids. Cancer Treat Rep 1976; 60: 1647-53.

7 Thaller C, Eichele G. Identification and spatial distribution of retinoids in the developing chick limb bud. Nature 1987; 327: 625-8.

8 Murtaugh MP, Dennison O, Stein JP, Davies PJ. Retinoic acid-induced gene expression in normal and leukemic myeloid cells. J Exp Med 1986; 163: 1325-30.

9 Ong DE, Chytil F. Multiple retinol binding proteins in rabbit lung. Biochem Biophys Res Commun 1974; 59: 221-9.

10 Sani BP. Localization of retinoic acid binding protein in nuclei. Biochem Biophys Res Commun 1977; 75: $7-12$.

11 Küng WM, Geyer E, Eppenberger U, Huber PR. Quantitative estimation of cellular retinoic acid-binding protein activity in normal, dysplastic and neoplastic human breast tissue. Cancer Res 1980; 40: 4265-9.

12 Palan PR, Romney SL. Cellular binding proteins for Vitamin $\mathrm{A}$ in human carcinomas and in normal tissues. Cancer Res 1980; 40: 4221-4.

13 Clamon GH, Nugent KM, Rossi NP. Cellular retinoic acid-binding protein in human lung carcinomas. $J$ Natl Cancer Inst 1981; 67: 61-3.

14 Fagg SL, Huges A, Fielding JWL, Dawson-Edwards P, Huges MA, Howie A. Retinoic acid receptor in human bladder tumors. Clin Oncol 1982; 8: 329-34.

15 Boyd D, Beynon L, Chrisholm DG, Habib FK. Characterization of the retinol and retinoic acid binding proteins in the human prostate. Cancer Res 1984; 44: 5532-7.

16 Jutley JK, Kelleher J, Whelan P, Mikel J. Cytosolic retinoic acid-binding protein in human prostatic dysplasia and neoplasia. The Porstate 1987; 11: 127-32.

17 Ong DE, Goodwin WJ, Jesse RH, Griffin AC. Presence of cellular retinol and retinoic acid-binding proteins in epidermoid carcinoma of the oral cavity and oropharynx. Cancer 1982; 49: 1409-12.

18 Bradford $M$. A rapid and sensitive method for the quantitation of microgram quantities of protein utilizing 
the principle of protein-dye binding. Ann Biochem 1976; 72: $248-54$.

19 Siegenthaler G, Saurat J. A slab gel electrophoresis technique for measurement of plasma retinol-binding protein, cellular retinol-binding and retinoic-acidbinding proteins in human skin. Eur J Biochem 1987; 166: $209-14$.

20 Chytil F, Ong DE. Cellular retinol- and retinoic-acid binding proteins in Vitamin A action. Fed Proc 1979; 38: 2510-4.

21 Ong DE, Page DL, Chytil F. Retinoic acid binding protein: occurrence in human tumors. Science $1975 ; 190$ : 60-1.

22 Bichler E, Daxenbichler G. Retinoic acid-binding protein in human squamous cell carcinomas of the ORL region. Cancer 1982; 49: 619-22.

23 Mitchell CJ, Jackson AM. Wai D. MacFie J. Guided percutaneous pancreatic biopsy. [Abstract] (jut 1988; 29: A266.

24 Schwartz JL, Firm SR, Shklar G. RA can alter the distribution of ATPase-positive Langerhan's cells in the hamster cheek pouch in association with DMBA application. Nutr Cancer 1985; 7: 77-84. 